\title{
A Customized and Flexible Ideal Mobile Banking System using 5G Technology
}

\author{
K. Krishna Prasad ${ }^{1} \&$ P. S. Aithal ${ }^{2}$ \\ ${ }^{1}$ Research Scholar, Rayalaseema University, Kurnool-518 007, Andra Pradesh, India \\ ${ }^{2}$ Department of Computer Science, Srinivas Institute of Management Studies, Pandeshwar, \\ Mangalore - 575 001, Karnataka, INDIA \\ E-mail: karanikrishna@gmail.com
}

Type of the Paper: Research Article.

Type of Review: Peer Reviewed.

Indexed in: OpenAIRE.

DOI: http://dx.doi.org/10.5281/zenodo.820860.

Google Scholar Citation: IJMTS

\section{How to Cite this Paper:}

Krishna Prasad, K., Aithal, P. S. (2017). A Customized and Flexible Ideal Mobile Banking System using 5G Technology. International Journal of Management, Technology, and Social Sciences (IJMTS), 2(1), 25-37.

DOI: http://dx.doi.org/10.5281/zenodo.820860.

International Journal of Management, Technology, and Social Sciences (IJMTS)

A Refereed International Journal of Srinivas University, India.

(C) With Authors.

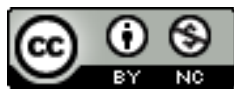

This work is licensed under a Creative Commons Attribution-Non Commercial 4.0 International License subject to proper citation to the publication source of the work.

Disclaimer: The scholarly papers as reviewed and published by the Srinivas Publications (S.P.), India are the views and opinions of their respective authors and are not the views or opinions of the SP. The SP disclaims of any harm or loss caused due to the published content to any party. 


\title{
A Customized and Flexible Ideal Mobile Banking System using 5G Technology
}

\author{
K. Krishna Prasad ${ }^{1}$ \& P. S. Aithal ${ }^{2}$ \\ ${ }^{1}$ Research Scholar, Rayalaseema University, Kurnool-518 007, Andra Pradesh, India \\ ${ }^{2}$ Department of Computer Science, Srinivas Institute of Management Studies, Pandeshwar, \\ Mangalore - 575 001, Karnataka, INDIA \\ E-mail: karanikrishna@gmail.com
}

\begin{abstract}
The word Ideal System refers to a system which is optimal or finest in terms of all its characteristics and any existing system can be improved or converted into the Ideal system by comparing existing system to Ideal system and by doing research and innovation. Mobile banking business will enable banking organizations to expand their markets, improve their services to all corners of the world without any barriers in terms of time, location and place. The rapid increase of mobile phone users is closely followed by security problems. The objective of this paper is to suggest some characteristics that will solve problems like security, bandwidth, network coverage, speed and much more. Fifth Generation (5G) mobile wireless communication technology an advanced modern upcoming technology that has significant change or difference in terms of bandwidth, speed access, and zone issues compare to its predecessors. In this paper, the concept of the Ideal mobile banking system is discussed, based on developing a suitable model with the predicted system and environmental characteristics which is ultimately very much user-friendly, customization and flexible in nature. To realize Ideal system model we have taken up 5G mobile wireless communication technologies and discussed how it will support Ideal mobile banking model by providing characteristics in terms of speed, bandwidth, data transfer rate, signaling efficiency and all advanced services. The paper makes an analysis of new model with its advantages, benefits, constraints, and disadvantages.
\end{abstract}

Keywords: Ideal Mobile Banking System, 5G Technology, Bandwidth, Customization, Flexible.

\section{INTRODUCTION :}

The advancement in Information and communication technology resulted in rapid growth of wireless mobile communication technology across the world. The word ideal refers to a system which is having peak performance characteristics in all aspects and will be helpful or beneficiary to all stakeholders and to society. In mobile banking service, customer or service provider should not find any difficulties in order to use or provide services. Mobile banking is a new form of banking services to customers to access and perform transactions anytime, anywhere through their smart mobile phones, which includes financial or nonfinancial transactions, utility bill payment, recharging of mobile, TV etc. A service model or system called ideal system, when that must have the following characteristics:

(i) An ideal model/system should capable of incorporating changes in services, or inclusion/deletion/updating of new/old services with out affecting in its overall framework or performance.

(ii) Postulation made in the model/system should be minimal.

(iii) The service should be the accessible $24 \times 7$ basis, every day.

(iv) The user interface should be simple, userfriendly and highly explanatory.

(v) The response time should be very good.

(vi) The error rate should be zero or nullified. 
(vii) Security should be very high or unauthorized access or use data by the unregistered user should be prevented.

A German company Paybox in collaboration with Deutsche Bank at first launched mobile banking in late 1990. In the beginning decade of the 21 century, some developing countries started introducing mobile banking services in that Kenya was the first developing country introduced m-banking service called M-Pesa, in 2007. Researchers used various terms for mobile banking, Amin et al., (2006) referred mobile banking as pocket banking, Ivatury and Mas, (2008) as branchless banking, while Donner and Tellez, (2008) called m-payments, m-transfers, m-finance and Liu et al., (2009) named as m-banking [1-4]. In Mobile Banking an ideal system refers a service system which is equally substitutable for all banking services. An ideal system should fill the gap between manual banking services and automated online banking services.

In this paper, we discuss an ideal mobile banking system which is finest in terms of all its characteristics or fulfills every aspects or need of users. Fifth Generation (5G) mobile wireless communication technology is an advanced modern upcoming technology. This paper discusses adoption of 5G technologies in mobile banking services and how this new technology significantly improves bandwidth, speed access, and zone issues. An ideal system is discussed with characteristics in terms of communication technology.

The Paper is structured under seven Sections. The First section describes an introduction to 5G Technology and definition of Ideal System. Section Two narrates about the ideal system in terms of communication system characteristics. Section Three describes characteristics and functions of 5G technology. The Section Four describes Ideal Mobile Banking System with its components and subcomponents with its technology and benefits. Section Five explains about applications of Ideal Mobile Banking System in Banking Functions. Section Six makes a real attempt to analyze the Ideal Mobile Banking System Model with its Advantages, Benefits, Constraints, and Disadvantages. Section Seven concludes the paper.

\section{IDEAL SYSTEM :}

It is well known that we can improve the performance of any system by comparing it with a hypothetical, predicted system of that kind called "Ideal system" [5-9]. The word 'Ideal system' refers to the system which has utmost characteristics, which cannot be improved further. It is what our mind tells ultimate and which reached the pinnacle of success in the respective field, which can be compared to all other systems of similar type, which lacks in some qualities [10-14]. The less-efficient system can be converted into the ideal system with the aid of research and continuous innovation in that field. Many objects we can consider as ideals like an ideal gas, ideal fluid, ideal engine, ideal switch, ideal voltage source, ideal current source, ideal semiconductor and ideal communication technology and all of these are considered as standards to improve the quality and performance of similar type. The ideal system of any kind can be placed in mind, while improving the characteristics of practical devices/ systems and reach ideal system or considered to be a pinnacle of success. Some of the ideal systems with respect to Telecommunications are listed in Table 1.

Table 1: List of Ideal components with respect to Telecommunications

\begin{tabular}{|l|l|l|}
\hline $\begin{array}{l}\text { Sr. } \\
\text { No. }\end{array}$ & $\begin{array}{l}\text { Ideal Systems/ } \\
\text { Components }\end{array}$ & Definition of ideal Systems/Components \\
\hline 1 & Ideal Bandwidth & $\begin{array}{l}\text { The Volume of information per unit of time that a } \\
\text { telecommunication system can handle is unlimited or } \\
\text { uncountable. }\end{array}$ \\
\hline 2 & Ideal Speed & $\begin{array}{l}\text { The time is taken in order to download or uploaded files are } \\
\text { within a second or negligible time. }\end{array}$ \\
\hline 3 & $\begin{array}{l}\text { Ideal Data Transfer } \\
\text { Rate }\end{array}$ & $\begin{array}{l}\text { Any amount of data can be transferred source to destination } \\
\text { within a few seconds. }\end{array}$ \\
\hline 4 & $\begin{array}{l}\text { Ideal Signaling } \\
\text { Efficiency }\end{array}$ & The quality of the signal is $100 \%$ efficient in all aspects. \\
\hline
\end{tabular}




\begin{tabular}{|l|l|l|}
\hline 5 & Ideal availability & $\begin{array}{l}\text { Signal or services can be available any part of the world at any } \\
\text { time i.e. } 24 * 365 \text { days without any disconnection. }\end{array}$ \\
\hline 6 & Ideal Security & $\begin{array}{l}100 \% \text { Protects personal information against misuse or } \\
\text { unauthorized access or highly robust security. }\end{array}$ \\
\hline 7 & Ideal roaming & $\begin{array}{l}\text { Worldwide interoperability and roaming between operators, } \\
\text { between users and service providers all time. The switching } \\
\text { between operates should take place freely.. }\end{array}$ \\
\hline 8 & Ideal Voice Quality & $\begin{array}{l}\text { Capacity to carry all types of voices all time, all over the world, } \\
\text { based on user's request. }\end{array}$ \\
\hline 9 & Ideal Video Quality & $\begin{array}{l}\text { Capacity to carry all types of videos without barriers to size, time } \\
\text { and place. } 100 \% \text { efficient video without streaming or buffering. }\end{array}$ \\
\hline 10 & Ideal Content & $\begin{array}{l}\text { Highly rich content without any difference between moving } \\
\text { content and ideal content. The content can be data, audio or video. }\end{array}$ \\
\hline
\end{tabular}

\section{FIFTH GENERATION TECHNOLOGY :}

Fifth generation mobile wireless technology is future wireless communication technology, which is not become reality as of now. But 5G aims to achieve very much higher capacity than current $4 \mathrm{G}$ in terms of many aspects of broadband user per unit area, bandwidth, speed, availability, super fast video services and many more fascinating and professional services. With the aid of 5G technology large population of the user can see and download audio, video, or any other multimedia services, without any restriction in terms of continuous, nonstop services with high efficiency [15-17]. The next generation mobile network alliance list out some standards for $5 \mathrm{G}$ technologies, which will cater the need of many wireless telecommunication based systems like mobile banking and e-learning, etc. It defines 5G technology in terms of several features [18-19] as

- Data rates of ten to fifteen of megabits per second for tens to fifteen of thousands or millions of users.

- Data rates 100-150 megabits per second or more for metropolitan areas focusing on more customers and retaining existing customers.

- The speed of more than 1-2 Gigabits per second simultaneously to many customers on the same office floor focusing on nearby area groups.

- Information rate that can be transmitted over specified bandwidth or spectral efficiency will be highly improved compared to 4G technologies using some advanced 5G technology.
- Billing services can be customized based on user requests and virtual private network.

- The virtual presence and virtual navigation can be highly improved compared to 4G technologies, especially in gaming 3D visualization and 3D image processing applications.

- Uploading and downloading speed of 5G technology are going to be improved and it will be in the rate of Terabytes or Petabytes, which is very much high compared to present 3G and 4G technology.

-5G technology expected to have an extra ordinary capacity to support different types of software and hardware interfaces which will cater the need of different highperformance systems.

- Multimedia services with ever seen efficiency anywhere, anytime and anyplace or ubiquitously, which will enrich and make fascinating different gaming and simulation systems.

-5G technology is promising to provided services without affecting to human health or eco-friendly and environment-friendly.

\section{IDEAL MOBILE BANKING SYSTEM :}

Ideal Mobile Banking System is a system which has properties like highly user-friendly, ubiquitous services, always available, very cheaper and $100 \%$ efficient in all aspects of banking or financial transactions [20-24]. As shown in figure 1, we have proposed an Ideal Mobile Banking Model, which consists of different components like Ideal Security, Ideal User-Friendly, Ideal Multimedia Services, Ideal Transactions, Ideal Loan Services and Ideal Auxiliary Services [25-28]. 


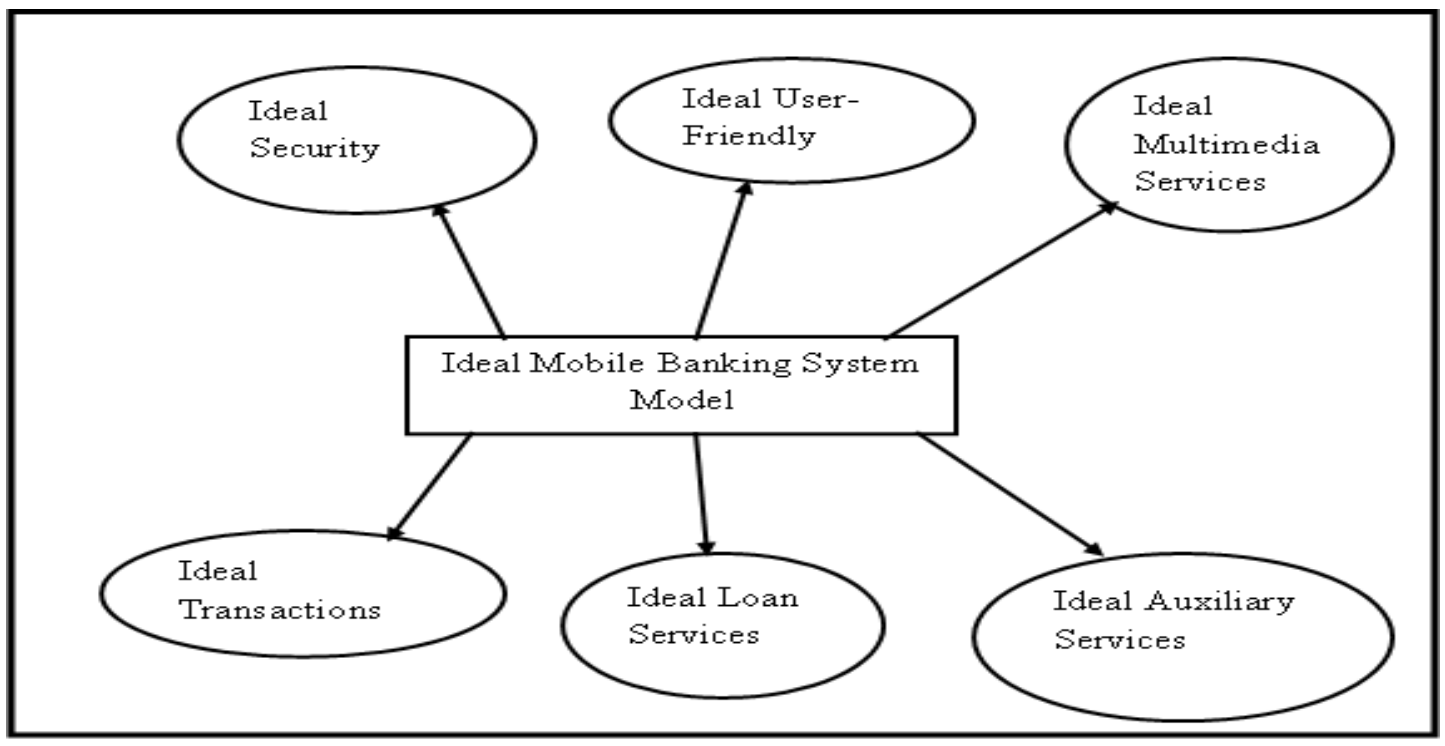

Figure 1: Ideal Mobile Banking System Model

\section{A. Ideal Security}

In Mobile Banking, Security refers Authentication, Confidentiality, Integrity, and Non-repudiation. These are referred using an ideal system as follows.

Ideal Authentication: Able to confirm that sender has right to send the message and receiver has the right to receive the message. A very strong or $100 \%$ secured authentication such that it ensures that the transaction takes place between only registered or already known parties. This can be achieved using multimodal and multilevel biometrics and other security measures with the aid of 5G technology.

Ideal Confidentiality: Message is encrypted in such a way that other than receiver and sender, no one else can be able to decrypt the message in any conditions. A very high or optimal password generating algorithm and a ciphering algorithm is used to implement Ideal confidentiality.

Ideal Integrity: Data is never altered or changed during its entire journey or transmission time while travelling from the source to destinations through various nodes. If the data is altered or compromised during transmission, the advanced hashing algorithm will generate a different digest value at the receiver side which will help the receiver to know that message has been altered during its transmission and receiver will reject the data. Ideal Integrity ensures that data never alters or if alters identified by the receiver and requests for re-transmission [29].

Ideal non-repudiation: Only the sender and receiver of the message are supposed to have the one-time password or security key and ideal Non-repudiation ensures that no other persons acquire security key. Each pair of onetime password and the sequence number is only allowed to be used for a single user and expires after its use within fraction of the time. Therefore the sender cannot deny not sending the message and receiver cannot deny not receiving because only those specific users have that unique pair of a password and sequence number to encrypt the message and it ensures that no one else can get OTP.

Table 2: Ideal Security Component's Technologies and Benefits

\begin{tabular}{|l|l|l|l|}
\hline $\begin{array}{l}\text { Sr. } \\
\text { No }\end{array}$ & $\begin{array}{l}\text { Security Sub } \\
\text { Components }\end{array}$ & Technologies & Benefits \\
\hline 1 & Ideal Authentication & $\begin{array}{l}\text { Multimodal Biometrics like-two } \\
\text { Fingerprints, voice recognition, etc. }\end{array}$ & $\begin{array}{l}\text { Only Authenticated } \\
\text { user get access to the } \\
\text { system. }\end{array}$ \\
\hline 2 & Ideal Confidentiality & $\begin{array}{l}\text { Optimal password and ciphering } \\
\text { algorithm based on hash functions. }\end{array}$ & $\begin{array}{l}\text { Decrypting of the } \\
\text { message by the } \\
\text { unknown user becomes }\end{array}$ \\
\hline
\end{tabular}




\begin{tabular}{|l|l|l|l|}
\hline 3 & Ideal Integrity & $\begin{array}{l}\text { Random Chaff Point Creation based } \\
\text { on hash functions. }\end{array}$ & $\begin{array}{l}\text { Data never alters or if } \\
\text { alters identified by the } \\
\text { receiver and requests } \\
\text { for re-transmission. }\end{array}$ \\
\hline 4 & Ideal non-repudiation & $\begin{array}{l}\text { Special Onetime password which } \\
\text { involves multiple factors. }\end{array}$ & $\begin{array}{l}\text { Sender and receiver } \\
\text { cannot deny sent and } \\
\text { received messages. }\end{array}$ \\
\hline
\end{tabular}

\section{B. Ideal User Friendly}

Ideal Mobile Banking Facility should be very much user-friendly for customers mean zero tolerance or difficulty while using facility or services. The user-friendly feature includes services like Ideal Availability, Ideal Data Freshness, Ideal Speed, and Ideal Bandwidth. Ideal Availability: The services should be available to all customers anytime, anywhere, any place without restriction to time and place or simply ubiquitously with 24*365 days basis. The user should able to access mobile banking services from geographically dispersed locations. The time it takes for a message to be delivered, usually depends on the density of nearby network operator base towers and ideal availability can ensure that base tower can accommodate any capacity of network load or density efficiently and effectively. In Ideal Mobile Banking System any number of transactions that the server can handle at once with ideal hardware capability. If the server hardware can handle hundred of multiple incoming messages then the server can handle multitasking or multiprogramming and simultaneously serve the user requests within no time. deal Data Freshness: The data, which is accessed or consumed by the user, should be fresh and ensures that no old message is replayed or re-transmitted. Ideal Data Freshness ensures that it is minimal or zero replayed attacks.

Ideal Speed: The speed at which user can upload or download any multimedia files can be measured in terms of Petabytes or more. Ideal speed ensures that mobile banking any transactions can be executed within no time or fraction of seconds.

Ideal Bandwidth: Volume of information per unit of time that mobile banking system can handle is unlimited or uncountable. Ideal Bandwidth ensures that all types of data can be reached to any locations within a fraction of the second.

Table 3: shows Ideal User-Friendly components technologies used while developing the system with the aid of 5G Technology, and also includes its benefits. The Ideal User-Friendly component should ensure that mobile banking system should be very much user-friendly to a user without any difficulty and should complete within no time and all facilities within the fingertip of a user.

Table 3: Ideal User Friendly Component's Technologies and Benefits

\begin{tabular}{|l|l|l|l|}
\hline $\begin{array}{l}\text { Sr. } \\
\text { No }\end{array}$ & $\begin{array}{l}\text { User Friendly sub } \\
\text { Components }\end{array}$ & Technologies & Benefits \\
\hline 1 & Ideal Availability & $\begin{array}{l}\text { High configuration hardware's, } \\
\text { more number of receiving towers, } \\
\text { high capacity satellite } \\
\text { communications and Advanced 5G } \\
\text { technologies. }\end{array}$ & $\begin{array}{l}\text { Services available to all } \\
\text { customers anytime, } \\
\text { anywhere, ubiquitously } \\
\text { with 24* 365 bases. } \\
\text { Services all time, all days } \\
\text { of the year. }\end{array}$ \\
\hline 2 & Ideal Freshness & Nonce and time-related counter. & $\begin{array}{l}\text { The data which is } \\
\text { accessed or consumed by } \\
\text { the user fresh and } \\
\text { ensures that no old } \\
\text { message is replayed or } \\
\text { re-transmitted }\end{array}$ \\
\hline 3 & Ideal Speed & $\begin{array}{l}\text { Open-distributed Ad-hoc network, } \\
\text { high capacity MIMO-OFDM, HC- } \\
\text { SDMA }\end{array}$ & $\begin{array}{l}\text { Any transactions or } \\
\text { applications can be } \\
\text { executed within fraction }\end{array}$ \\
\hline
\end{tabular}




\begin{tabular}{|l|l|l|l|}
\hline & & & of seconds. \\
\hline 4 & Ideal Bandwidth & $\begin{array}{l}\text { High capacity Spectrum, more } \\
\text { capacity frequency band and Time } \\
\text { Division Duplexing (TDD) }\end{array}$ & $\begin{array}{l}\text { All types of data can be } \\
\text { reached to any locations } \\
\text { within a fraction of a } \\
\text { second. }\end{array}$ \\
\hline
\end{tabular}

\section{C. Ideal Multimedia Services}

Ideal Multimedia Services component of Ideal Mobile Banking System Model consists of Ideal Data, Ideal Audio, Ideal Video and Ideal Broadband.

Ideal Data: This ensures that any type of data, in terms of size and file type can be transferred or moved between source and destinations without any restrictions in any aspects. Data can be easily added deleted or can be used in any type of financial or nonfinancial transactions.

Ideal Audio: High capacity audio can be transmitted, uploaded or downloaded within a fraction of seconds. The quality of Audio is $100 \%$ perfect in all qualities. Audi signal is having some ideal qualities like higher sampling rate with more bits per sample or Bit rate, instantly cut and audio file in half to convert stereo to mono, optimal file size with lossy compression and universal compatible file format.
Ideal Video: Full High-Density Video (Full HD-VIDEO) can be transmitted to any source to destination, all over the world without any restrictions in terms of time, size and locations. Live Streaming Video can be broadcasted to any locations efficiently and effectively.

Ideal Broadband: Without hotspot mobile users can connect to the internet and access seamless broadband services across the world. Ideal broadband services will be having features like always connected, omnipresent, high speed and high efficiency.

Table 4 shows Ideal Multimedia Services technologies used while developing the system with the aid of 5G Technology, and also includes its benefits. The Ideal Multimedia Services component should ensure that mobile banking system should be very much efficient in handling audio, video and data files of any size.

Table 4: Ideal Multimedia Services Component's Technologies and Benefits

\begin{tabular}{|c|c|c|c|}
\hline $\begin{array}{l}\text { Sr. } \\
\text { No }\end{array}$ & $\begin{array}{l}\text { Multimedia Sub } \\
\text { components }\end{array}$ & Technologies & Benefits \\
\hline 1 & Ideal Data & $\begin{array}{lrr}\text { Advanced } & \text { OFDMA } & \text { Flat } \\
\text { Architecture, } & \text { True } & \text { Packet } \\
\text { Switched, Unified IP } & \end{array}$ & $\begin{array}{l}\text { Data can be easily added deleted, } \\
\text { uploaded, downloaded and } \\
\text { transmitted to any locations easily } \\
\text { and effectively. }\end{array}$ \\
\hline 2 & Ideal Audio & 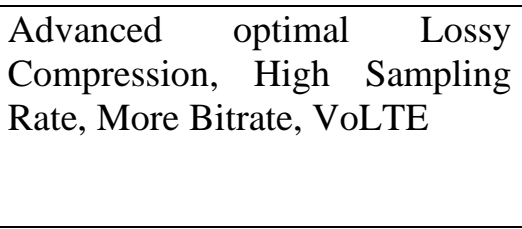 & $\begin{array}{l}\text { High capacity audio can be } \\
\text { transmitted, uploaded } \\
\text { downloaded within a fraction of } \\
\text { seconds. The quality of Audio is } \\
100 \% \text { perfect in all qualities. }\end{array}$ \\
\hline 3 & Ideal Video & $\begin{array}{l}\text { Advanced } \quad \text { base-station } \\
\text { Backhaul, Ultra-Wide Band } \\
\text { Networks, Smart Antennas }\end{array}$ & $\begin{array}{l}\text { Full High-Density Video (Full } \\
\text { HD-VIDEO) can be transmitted to } \\
\text { any source to destination, all over } \\
\text { the world without any restrictions } \\
\text { in terms of time, size and } \\
\text { locations. }\end{array}$ \\
\hline 4 & Ideal Broadband & 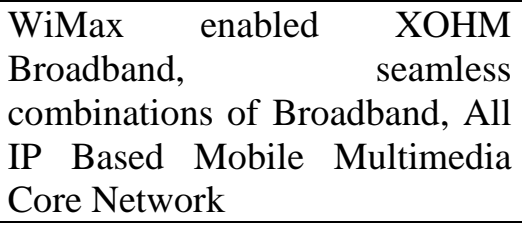 & $\begin{array}{l}\text { Without hotspot mobile users can } \\
\text { connect to the internet and access } \\
\text { seamless broadband services } \\
\text { across the world. High-capacity } \\
\text { Internet Services. }\end{array}$ \\
\hline 4 & Ideal Broadband & $\begin{array}{lr}\begin{array}{l}\text { WiMax enabled } \\
\text { XOHM } \\
\text { Broadband, }\end{array} \\
\text { seamless }\end{array}$ & $\begin{array}{l}\text { Without hotspot mobile users } \\
\text { can connect to the internet and }\end{array}$ \\
\hline
\end{tabular}




\begin{tabular}{|l|l|l|l|}
\hline & $\begin{array}{l}\text { combinations of Broadband, } \\
\text { All IP Based Mobile } \\
\text { Multimedia Core Network }\end{array}$ & $\begin{array}{l}\text { access seamless broadband } \\
\text { services across the world. High- } \\
\text { capacity Internet Services. }\end{array}$ \\
\hline
\end{tabular}

\section{D. Ideal Transactions}

Ideal Transactions component of Ideal Mobile Banking System Model includes Ideal Digital Deposit, Ideal Digital Withdrawal, and Ideal Money Transfer. Ideal Transactions ensures that customer should able to perform banking transactions easily, effectively and zero tolerance or effort. The customer should do every banking transaction without actually visiting bank branches or virtually from any places.

Ideal Digital Deposit: Customer should able to deposit cheque using their mobile phone, from any place, at any time. The user takes an image of the cheque using the camera of Smartphone and sends that image to the bank server, server process the request and deposits required the amount to the users account. In Ideal Digital Deposit, depositing should become as simple as depositing money in old fashion paper cheque, without any queuing system.

Ideal Digital Withdrawal: Customer should able to handle money without physically

Withdrawing money from their account, which means that customer should able to do any transactions without carrying money physically. All transactions related to money will be carried out online. Ideal Digital Withdrawal ensures that customer should not find any difficulty to handle online transactions or digital money, which will be very simple and everyone should able to do it without any effort.

Ideal Money Transfer: Customer can transfer money to self or others, within the same bank or other banks ubiquitously with zero effort or tolerance. Ideal Money Transfer ensures that money is transferred to any account all times $24 * 365$ days of the year basis.

Table 5 shows Ideal Transactions technologies used while developing the system with the aid of 5G Technology, and also includes its benefits. The Ideal Transactions component should ensure that mobile banking system should be very much efficient in handling banking transactions with zero effort or tolerance.

Table 5: Ideal Transaction Component's Technologies and Benefits

\begin{tabular}{|l|l|l|l|}
\hline $\begin{array}{l}\text { Sr. } \\
\text { No }\end{array}$ & $\begin{array}{l}\text { Ideal Transactions Sub } \\
\text { components }\end{array}$ & Technologies & Benefits \\
\hline 1 & Ideal Digital Deposit & $\begin{array}{l}\text { Advanced Mobile Camera, } \\
\text { IP Based Radio Access } \\
\text { Network, }\end{array}$ & $\begin{array}{l}\text { Depositing should become as } \\
\text { simple as depositing money in old } \\
\text { fashion paper cheque, without any } \\
\text { queuing system }\end{array}$ \\
\hline 2 & Ideal Digital Withdrawal & $\begin{array}{l}\text { Packet Data Serving Node, } \\
\text { Base Station Controller, W- } \\
\text { CDMA }\end{array}$ & $\begin{array}{l}\text { The customer should not find any } \\
\text { difficulty to handle online } \\
\text { transactions or digital money, } \\
\text { which will be very simple and } \\
\text { everyone should able to do it } \\
\text { without any effort. }\end{array}$ \\
\hline 3 & Ideal Money Transfer & $\begin{array}{l}\text { Packet Data Serving Node, } \\
\text { Base Station Controller, W- } \\
\text { CDMA, Wi-Max }\end{array}$ & $\begin{array}{l}\text { Money is transferred to any } \\
\text { account all times 24*365 days of } \\
\text { the year basis. }\end{array}$ \\
\hline
\end{tabular}

\section{E. Ideal Loan Services}

Usually, in the present scenario, a customer finds difficulty, while taking a loan from the bank. Before sectioning a loan bank has to verify several documents if documents proper then the only bank will provide a loan to customers. Also, it should evaluate several eligibility criteria before providing a loan. All these processes take several days or months. An ideal Loan service includes house loan, Vehicle loan and personal loans.

Table 6 shows Ideal Loan Services technologies used while developing a system with the aid of 5G Technology. The Ideal Loan Services component should ensure that mobile banking system should be very much 
efficient in and handling Loan services with low time duration efficiently.

Table 6: Ideal Loan Services Component's Technologies and Benefits

\begin{tabular}{|l|l|l|l|}
\hline $\begin{array}{l}\text { Sr. } \\
\text { No }\end{array}$ & $\begin{array}{l}\text { Ideal Lervices } \\
\text { Component }\end{array}$ & Technologies & Benefits \\
\hline 1 & Ideal Loan Services & $\begin{array}{l}\text { High-Density Video } \\
\text { Conferencing, } \\
\text { Advanced VoLTE, }\end{array}$ & $\begin{array}{l}\text { The effort and time should be reduced for } \\
\text { customers while availing loan services } \\
\text { from the bank. Customer should not find } \\
\text { any difficulties while availing House Loan, } \\
\text { Vehicle Loan, Personal Loan and any } \\
\text { other types of Loan. }\end{array}$ \\
\hline
\end{tabular}

\section{F. Ideal Auxiliary Services}

Mobile Banking System can be used for many purposes other than banking financial or nonfinancial transactions. Mobile Banking System can be used for LIC premium payment, Gas Booking, Mobile Recharge, Income Tax payment, D2H recharge, Grocery purchase or any other types of purchases. Ideal Auxiliary Services ensures the user can able to all these services without any effort or difficulty. Table 7 shows Ideal Auxiliary Services technologies used while developing a system with the aid of 5G Technology, and also includes its benefits. The Ideal Auxiliary Services component should ensure that mobile banking system should be very much efficient in handling Auxiliary services efficiently and as like they do manual transactions.

Table 7: Ideal Auxiliary Services Component's Technologies and Benefits

\begin{tabular}{|l|l|l|l|}
\hline $\begin{array}{l}\text { Sr. } \\
\text { No }\end{array}$ & $\begin{array}{l}\text { Ideal Auxiliary } \\
\text { Services } \\
\text { Components }\end{array}$ & Technologies & Benefits \\
\hline 1 & $\begin{array}{l}\text { Ideal Auxiliary } \\
\text { Services }\end{array}$ & $\begin{array}{l}\text { Advanced H-CDMA, Ad-Hoc } \\
\text { Networks AMC, MIMO- } \\
\text { OFDM, Advanced WiMax }\end{array}$ & $\begin{array}{l}\text { All the money related services } \\
\text { other than banking services can be } \\
\text { able to perform with zero tolerance } \\
\text { and user should find it utmost } \\
\text { user-friendly. }\end{array}$ \\
\hline
\end{tabular}

\section{APPLICATIONS OF IDEAL MOBILE}

\section{BANKING SYSTEM :}

As shown in Table 8, in this section we discuss each component of Ideal Mobile Banking System Model and its applications in various mobile banking services in Tabular Form.
Ideal Mobile Banking System includes different components as Ideal Security, Ideal User-Friendly, Ideal Multimedia Services, Ideal Transactions, Ideal Loan Services and Ideal Auxiliary Services.

Table 8: Ideal Mobile Banking System-Applications

\begin{tabular}{|l|l|l|l|}
\hline $\begin{array}{l}\text { Sr. } \\
\text { No }\end{array}$ & $\begin{array}{l}\text { Ideal Banking } \\
\text { System } \\
\text { Components }\end{array}$ & $\begin{array}{l}\text { Ideal banking System } \\
\text { Sub- components }\end{array}$ & Applications \\
\hline 1 & Ideal Security & Ideal Authentication & $\begin{array}{l}\text { Only Authenticated user get access to mobile } \\
\text { banking portal }\end{array}$ \\
\cline { 3 - 4 } & Ideal Confidentiality & $\begin{array}{l}\text { While sending messages in the mobile banking } \\
\text { system, decrypting of the messages by the } \\
\text { unknown person becomes impossible. }\end{array}$ \\
\cline { 3 - 4 } & Ideal Integrity & $\begin{array}{l}\text { In Mobile Banking System, while transmitting } \\
\text { data through a network, data never alters or if } \\
\text { alters identified by the receiver and requests for } \\
\text { re-transmission. }\end{array}$ \\
\cline { 3 - 4 } & Ideal non-repudiation & \begin{tabular}{l} 
In Mobile Banking System, sender and receiver \\
\hline
\end{tabular} \\
\hline
\end{tabular}




\begin{tabular}{|c|c|c|c|}
\hline & & & $\begin{array}{l}\text { cannot argue that they have not sent or received } \\
\text { the transmitted message. }\end{array}$ \\
\hline \multirow[t]{4}{*}{2} & \multirow[t]{4}{*}{$\begin{array}{ll}\text { Ideal } & \text { User- } \\
\text { Friendly } & \end{array}$} & Ideal Availability & $\begin{array}{l}\text { Mobile Banking } \\
\text { ubiquitously. }\end{array}$ \\
\hline & & Ideal Freshness & $\begin{array}{l}\text { User will receive fresh and updated data while } \\
\text { using Mobile Banking System. }\end{array}$ \\
\hline & & Ideal Speed & $\begin{array}{l}\text { Mobile Banking Services or transaction speed } \\
\text { is very high in terms of Petabytes. }\end{array}$ \\
\hline & & Ideal Bandwidth & $\begin{array}{l}\text { Mobile Banking System Bandwidth will } \\
\text { improve; it may be several hundred times of } \\
\text { present bandwidth. }\end{array}$ \\
\hline \multirow[t]{4}{*}{3} & \multirow[t]{4}{*}{$\begin{array}{l}\text { Ideal } \\
\text { Multimedia } \\
\text { Services }\end{array}$} & Ideal Data & $\begin{array}{l}\text { Mobile Banking System will accommodate } \\
\text { high capacity data, which can be uploaded, } \\
\text { downloaded at any time without any effort. } \\
\text { Data can be transmitted easily through the } \\
\text { network. }\end{array}$ \\
\hline & & Ideal Audio & $\begin{array}{l}\text { Mobile Banking System can utilize high } \\
\text { capacity audio, which will be very useful while } \\
\text { calling. }\end{array}$ \\
\hline & & Ideal Video & $\begin{array}{l}\text { Mobile Banking System will witness high } \\
\text { capacity video conferencing services. }\end{array}$ \\
\hline & & Ideal Broadband & $\begin{array}{l}\text { Mobile Banking System will enrich with super } \\
\text { fast and super efficiency broadband services } \\
\text { which will help in video conferencing, and all } \\
\text { type of high volume transactions. }\end{array}$ \\
\hline \multirow[t]{3}{*}{4} & \multirow{3}{*}{$\begin{array}{l}\text { Ideal } \\
\text { Transaction } \\
\text { Services }\end{array}$} & Ideal Digital Deposit & $\begin{array}{l}\text { Mobile Banking System will support for digital } \\
\text { deposit of cheque easily anywhere, anytime. }\end{array}$ \\
\hline & & $\begin{array}{ll}\text { Ideal } & \text { Digital } \\
\text { Withdrawal } & \\
\end{array}$ & $\begin{array}{l}\text { Mobile Banking System will support for digital } \\
\text { or cashless transactions. }\end{array}$ \\
\hline & & Ideal Money Transfer & $\begin{array}{l}\text { Through Mobile Banking System users can } \\
\text { transfer money to self or to any account without } \\
\text { any barriers in terms of time, place, and } \\
\text { locations. }\end{array}$ \\
\hline 5 & $\begin{array}{ll}\text { Ideal } & \text { Loan } \\
\text { Services } & \end{array}$ & $\begin{array}{l}\text { Home Loan, Vehicle } \\
\text { Loan, and Personal } \\
\text { Loan }\end{array}$ & $\begin{array}{l}\text { Mobile Banking System will reduce the hurdles } \\
\text { and efforts of availing loan facility for } \\
\text { customers. }\end{array}$ \\
\hline 6 & $\begin{array}{l}\text { Ideal Auxiliary } \\
\text { Services }\end{array}$ & $\begin{array}{l}\text { D2H recharge, Mobile } \\
\text { recharge, Gas booking, } \\
\text { and online purchases } \\
\text { etc. }\end{array}$ & $\begin{array}{l}\text { Mobile Banking System will support for all } \\
\text { auxiliary or subsidiary services efficiently, } \\
\text { which will greatly reduce the burden of users in } \\
\text { the payment process. }\end{array}$ \\
\hline
\end{tabular}

\section{ANALYSIS OF IDEAL MOBILE BANKING SYSTEM :}

The Ideal Mobile Banking System is analyzed in terms of its advantages, Benefits, Constraints, and Disadvantages. Ideal Mobile Banking System model is a conceptual model that ensures some ideal characteristics like better availability, accessibility, user friendliness features, security, speed and Bandwidth with the aid of 5G technology.

\section{Advantages}

- Ideal solution for paper-free Banking Transactions

- Transaction facility anywhere, anytime and constraint-free or ubiquitously

- Digital deposit of cheque makes customer effort free and time saving

- Ever seen, ever imagined Speed, Bandwidth, security due to $5 \mathrm{G}$ technology

- Bill payment makes simple and effortless

- Automatic digital withdrawal helps to improve cashless society 
- Smart Phone Credit Card Scanning improves security of customer PIN

- Electronic meeting and video conferencing save customer time and simple.

- Highly user-friendly and interactive interface

- Always available data is updated and fresh

- All bills can be paid without visiting respective offices or from remote place easily

- Usage experience of smartphone helps to learn the mobile banking

- 5G Technology makes services more attractive, effective, and omnipresent and ubiquitous

- Unified single standard for wireless communication and global roaming facility due to 5G Technology

\section{Benefits}

- Global expansion of Smart Phone banking services helps to acquire new customers or to retain the existing customers all over the world

- The ability to obtain a larger customer pool and appreciations due to ideal and ubiquitous services.

- The ability to take advantage of the growing popularity of Smart Phone banking through Digital Deposit, Digital Withdrawal, and Auxiliary Services makes customer effort free and happy.

- Enhances reputation of the bank by providing fast and secured, always available and ideal services to its customer

- Banks can able to attract all types of busy schedule customers, which includes Business people, Software engineers or other tight scheduled customer pool.

- Improves customer satisfaction and faithfulness

- Loan services can be effectively improved that helps to improve the bank turnover

\section{Constraints}

- 5G Technology is not yet developed, so many functionalities of 5G technology not known

- High cost to implement services

- Computer and mobile literacy is compulsory to use the system

- Lack of technical support

- Lack of trained and skilled persons

- Realizing ideal quality in all areas is very difficult

\section{Disadvantages}

- Requirement of high memory, processors and latest technology at Bank's servers

- Possible failure to achieve ideal qualities in all areas

- Lack of technically sound staff

- Initial investment in technology will be expensive, which will slow down the starting of new services initiation by the bank

- Lack of trained staff

- Electronic meeting some time misused by the customers in loan services

-5G Technology become more expensive during its initial design and implementation

\section{CONCLUSION :}

Ideal systems are those systems which will be comparable to any other system and system which wants to improve can take reference as that system and steps forward to achieve the pinnacle of success in every aspects. The 5G, future advanced wireless communication technologies will offer a variety of services like mobile internet, mobile commerce, and bill payment services with ever pleasant, highly sophisticated and super fast nature and will utilize advanced technologies like OFDMA, IP Based Radio Access Network, Packet Data Serving Node, Base Station Controller and W-CDMA, etc.

In this paper we tried to explain Ideal Mobile Banking System Characteristics through Ideal Mobile Banking System Model which includes different components like Ideal Security, Ideal User-Friendly, Ideal Multimedia Services, Ideal Transactions, Ideal Loan Services and Ideal Auxiliary Services. Each component has some sub components. We explained each components and sub components technologies and benefits through tabular the form. We also explained applications of these components in Mobile Banking Scenario. Finally we analyzed new model using its advantages, Benefits, Constraints, and Disadvantages.

\section{REFERENCES :}

[1] Amin, H., Hamid, M. R. A., Tanakinjal, G. H., \& Lada, S. (2006). Undergraduate attitudes and expectations for mobile banking. Journal of Internet Banking and Commerce, 11(3).

[2] Ivatury, G., \& Mas, I. (2008). The early experience with branchless banking. 
[3] Donner, J., \& Tellez, C. A. (2008). Mobile banking and economic development: Linking adoption, impact, and use. Asian journal of communication, 18(4), 318332.

[4] Liu, Z., Min, Q., \& Ji, S. (2009). An empirical study on mobile banking adoption: The role of trust. In Electronic Commerce and Security, 2009. ISECS'09. Second International Symposium, 2,7-13.

[5] Aithal P. S., and Shubhrajyotsna Aithal(2015). Ideal Technology Concept \& its Realization Opportunity using Nanotechnology, International Journal of Application or Innovation in Engineering \& Management (IJAIEM), 4(2), 153 164.

[6] Aithal P. S. (2015, March). Concept of Ideal Business \& Its Realization Using EBusiness Model. International Journal of Science and Research (IJSR), 4(3), 12671274.

[7] Aithal P. S. (2015, July). Mobile Business as an Optimum Model for Ideal Business. International Journal of Management, IT and Engineering (IJMIE), 5(7), 146-159.

[8] Aithal P. S. and Shubhrajyotsna Aithal (2015, March). An Innovative Education Model to realize Ideal Education System, International Journal of Scientific Research and Management (IJSRM), 3(3), $2464-2469$.

[9] Aithal P. S. and Shubhrajyotsna Aithal (2014). Ideal education system and its realization through online education model using mobile devices, Proceedings of IISRO Multi Conference 2014, Bangkok, 7/01/2014, 140 - 146. ISBN No. 978-81-927104-33-13.

[10] Aithal P. S., \& Shubhrajyotsna Aithal (2016). Impact of On-line Education on Higher Education System, International Journal of Engineering Research and Modern Education (IJERME), 1(1), 225235.

[11] Aithal P. S., The concept of Ideal Strategy \& its realization using White Ocean Mixed Strategy, International Journal of Management Sciences and Business Research (IJMSBR), 5(4), 171-179.
[12] Sridhar Acharya P. and Aithal P. S. (2016). Concepts of Ideal Electric Energy System FOR production, distribution and utilization, International Journal of Management, IT and Engineering (IJMIE), 6(1), 367-379.

[13] Aithal P. S. (2016, June). Concept of Ideal Banking and Realization of it using Ubiquitous Banking, Submitted to International Journal of Information Engineering and Electronic Business(IJIEEB).

[14] Aithal P. S. (2016). Concept of Smart Library Models for Future Generations, Proceedings of National Conference on Changing Perspectives of Management, IT, and Social Sciences in Contemporary Environment, Manegma 2016, SIMS, Mangalore, India, 14, 50-62. ISBN 97893-5265-6523.

[15] Andrews, J. G., Buzzi, S., Choi, W., Hanly, S. V., Lozano, A., Soong, A. C., \& Zhang, J. C. (2014). What will 5G be?. IEEE Journal on selected areas in communications, 32(6), 1065-1082.

[16] Patil, S., Patil, V., \& Bhat, P. (2012). A review on 5G technology. International Journal of Engineering and Innovative Technology (IJEIT), 1(1), 26-30.

[17] Krishna Prasad, K., \& Aithal, P. S. (2016). Changing Perspectives of Mobile Information Communication Technologies towards Customized and Secured Services through 5G \& 6G. International Journal of Engineering Research and Modern Education (IJERME), 1(2), 210-224.

[18] Mousa, A. M., (2012). Prospective of fifth generation mobile communications. International Journal of Next-Generation Networks (IJNGN), 4(3), 1-30.

[19] Singh, S., \& Singh, P., (2012). Key concepts and network architecture for 5G mobile technology. International Journal of Scientific Research Engineering \& Technology (IJSRET), 1(5), 165-170.

[20] Krishna Prasad, K., \& Aithal, P. S. (2015). Massive Growth of Banking Technology with the Aid of 5G Technologies. International Journal of 
Management, IT and Engineering, 5(7), 616-627.

[21] Krishna Prasad, K., \& Aithal, P. S. (2016). The Growth of 4G Technologies in India-Challenges and Opportunities. International Journal of Management, IT and Engineering, 6(1), 543-351.

[22] Krishna Prasad, K., \& Aithal, P. S. (2016). An Online Comparative Study on 4G Technologies Service Providers in India. International Journal of Advanced Trends in Engineering and Technology (IJATET). 1(1), 96-101.

[23] Krishna Prasad, K. and Aithal, P. S. (2017). A Study on Enhancing Mobile Banking Services using Location based Authentication . International Journal of Management, Technology, and Social Sciences (IJMTS), 1(1), 48-60. DOI:http://doi.org/10.5281/zenodo.58323 0 .

[24] K. Krishna Prasad (2016). Blog Based Self Verification And Self Development Curriculum Model-A Novel Approach To Student Centric Learning. International journal of Scientific Research and Modern Education, 1(1), 435-441 (June 2016) ISSN-2455 - 5630.

[25] Sumanjeet, S. (2009). Emergence of payment systems in the age of electronic commerce: The state of art.

[26] Koenig-Lewis, N., Palmer, A., \& Moll, A. (2010). Predicting young consumers' take up of mobile banking services. International journal of bank marketing, 28(5), 410-432.

[27] Debnath, A., \& Abhinandan (2013). Review on NEXT Generation Technologies of Wireless Communication. International Journal on Recent and Innovation Trends in Computing and Communication, 1(4), pp.346-350.

[28] Pachauri, A. K., \& Singh, O. (2012). 5G Technology-Redefining wireless Communication in upcoming years. International Journal of Computer Science and Management Research, 1(1), pp.12-19.
[29] Mohammad Khalaf and Rahim Aljuaifari. (2015). Secure SMS Mobile Transaction with Peer to Peer Authentication Design for Mobile Government. American Journal of Engineering Research (AJER), 4(11), 143-149. 